\title{
Securitisation from below: The relationship between immigration and foreign policy in South Africa's approach to the Zimbabwe crisis
}

\author{
By Anne Hammerstad
}

\section{5 word abstract}

The political and economic debacle in Zimbabwe has led to a large-scale influx of Zimbabweans into neighbouring South Africa. This article argues that there is a complex and significant link between the domestic response to this immigration influx and South Africa's foreign policy towards Zimbabwe. South Africa's foreign and security policy elite preferred to use an immigration approach of benign neglect as a tool to promote its 'quiet diplomacy' approach towards the Zimbabwean regime, treating the influx as a 'non-problem'. But increased xenophobic violence, vigilantism and protests in townships and informal settlements against Zimbabwean and other African immigrants, culminating in widespread riots across the country in 2008, contributed to a change not only in immigration policy but also in the mediation efforts towards the Zimbabwean parties. I argue that this foreign policy change was pushed by a process of 'securitisation from below', where the understanding of Zimbabwean immigrants as a security threat were promoted not by traditional security elites but by South Africa's marginalised urban poor.

\section{Biography, email and postal contact details}

Dr Anne Hammerstad is lecturer in International Relations at the University of Kent, ESRC Global Uncertainties Fellow and Research Associate at the South African Institute of International Affairs (SAIIA). She currently pursues an ESRC funded research programme 
within the RCUK Global Uncertainties fellowship scheme on 'The securitisation of forced migration: ideas and beliefs about displacement and their impact on security'.

Email address:

a.hammerstad@kent.ac.uk

Postal address:

School of Politics and IR

University of Kent

Canterbury

Kent CT2 7NX 


\section{Securitisation from below: The relationship between immigration and}

\section{foreign policy in South Africa's approach to the Zimbabwe crisis}

\section{Introduction}

The drawn-out political and economic crisis in Zimbabwe has posed serious challenges to neighbouring South Africa. In the area of foreign policy, South Africa's apparent inability to bring about a resolution to the imbroglio has dented its international reputation as a regional and emerging power. South Africa's Zimbabwe policy has been described as 'perplexing'1, a sign of its 'moral decline', , or even proof that it has become 'the despots' democracy' ${ }^{3}$ In addition to this foreign policy cost, domestic South African politics have also been adversely affected. South Africa is host to somewhere between 1.5 and three million Zimbabweans, and has since 2008 become the world's most popular destination for asylum seekers. ${ }^{4}$ The popular response to this influx of undocumented immigrants and asylum seekers has become increasingly hostile and fearful, culminating in widespread xenophobic riots in 2008. The riots left 62 people dead, while tens of thousands of foreign nationals fled into internal displacement camps. 5

While these foreign policy and domestic immigration policy challenges caused by the Zimbabwe crisis have each and separately received ample scholarly attention, ${ }^{6}$ few have attempted to explore the complex but significant links between South Africa's foreign policy towards Zimbabwe and its immigration policies towards Zimbabweans. This article aims to demonstrate that domestic immigration policy is not necessarily secondary to the 'high politics' of foreign policy. While the policy response of South Africa's African National Congress (ANC) government to the mass influx of Zimbabwean immigrants can to some extent be understood as supporting its foreign policy goals towards Zimbabwe, a closer analysis shows a complex inter-relationship between foreign and immigration policy. This article argues that 
as the Zimbabwe debacle has dragged on, domestic concern over immigration has played an increasingly significant role not just in shaping immigration policy but also in influencing South Africa's foreign policy towards Zimbabwe.

The analysis takes place within the framework of securitisation theory. ${ }^{7}$ The question underlying this study is why growing xenophobic violence, vigilantism and volatility within South Africa received little attention for so long by the country's foreign and security policy elite. I argue that this is because South Africa's immigration approach towards the mass influx of Zimbabweans was for a long time broadly geared towards supporting foreign policy goals rather than addressing domestic concerns. But, importantly, since 2008 the influence began to also flow in the other direction, leading the government to strike an uneasy compromise between addressing immigration concerns and xenophobia, on the one hand, and furthering its foreign policy aims, on the other. This article studies the reasons behind this development and suggests it is the result of a gradual securitisation of Zimbabwean immigration.

The increased salience of immigration concerns in influencing South Africa's foreign policy towards Zimbabwe is the result of a three-stage securitisation process: First, the evolution in the 1990s of a xenophobic public discourse on African immigration, fuelled by the Department of Home Affairs (DHA). Second, a hostile grassroots level response to the mass influx of Zimbabweans from the early 2000s onwards, as segments of South Africa's poorer citizenry perceived Zimbabwean immigrants as threats to jobs, health and welfare. Finally, this grassroots level securitisation, increasingly manifested in violence, riots and social and political tension in townships and informal settlements, led to an elite level securitisation of a different kind. South Africa's traditional foreign and security policy elite did not, and still do not, see Zimbabwean immigration as a security threat in itself, but after the 2008 xenophobic riots it began to perceive the reaction to this immigration as a potential threat to domestic stability. As 
a result, immigration concerns started from late 2008 onwards to play a role in the ANC government's handling of the Zimbabwe crisis.

The securitisation process of Zimbabwean immigration is unusual. It resulted not from overt pronouncements by a traditional security policy elite, but despite this elite's attempt at treating the influx as a non-problem. I describe this process as securitisation from below, since the main securitising actors do not hold positions of influence and authority but belong to the disempowered margins of South Africa's politics.

I divide the argument into four sections. First, I present the securitisation framework and develop an analytical grid of securitising actors and audiences to be deployed in the analysis of the securitisation of Zimbabwean immigration. This done, section two sets out the main ideas, beliefs and perceptions that make up the government's foreign policy discourse. Section three does the same for South Africa's immigration discourse. I describe the former as a 'foreign policy discourse of African solidarity', while the latter is denoted the 'Home Affairs xenophobic discourse'. Section four analyses how the contradictory relationship between these two discourses evolved over the course of the Zimbabwe crisis. From 2000 to 2008, the period covering the onset, deterioration and nadir of the Zimbabwe crisis, South Africa's foreign policy goals, embodied in its 'quiet diplomacy' approach towards the Zimbabwean regime, go a long way towards explaining the (lack of) immigration regime put in place to deal with the Zimbabwean influx. This changed in 2008, when a humanitarian emergency in Zimbabwe led to an unprecedented influx of desperate Zimbabweans and deadly xenophobic riots broke out across South Africa. The agonised soul searching following the riots contributed to a noticeably firmer South African diplomacy towards the parties to the Zimbabwe conflict; a more critical stance towards the ruling ZANU-PF; closer government attention to domestic anti-immigrant sentiments; and attempts at regularising and controlling the Zimbabwean influx. 
The article concludes with two sets of observations. First, it sums up the complex dynamics of the securitisation process of Zimbabwean immigration and its eventual impact on South African foreign policy. Second, it draws on this study of securitisation from below to provide some conclusions on the analytical framework of the securitisation approach. This said, the argument in this article is not theory driven. The main aim is to further our understanding of the relationship between immigration and immigration responses, on the one hand, and foreign policy choices on the other, in the case of South Africa.

\section{Securitisation from below: an analytical framework}

There has been a constructivist turn in security studies over the past couple of decades, predicated on the observation that security threats are not objectively given realities, but intersubjectively constituted through social processes. ${ }^{8}$ Our understanding of the phenomenon of migration is perhaps the best example of this: the tendency to perceive human movement through a security lens has become increasingly common over the past couple of decades. ${ }^{9}$ One way of explaining this trend is to describe some aspects of migration and some types of migrants as having become securitised: Instead of being discussed as a political, social or economic challenge, migration is framed in the language of existential and urgent threat, as dictated by the concept of security. ${ }^{10}$

The securitisation approach, first formulated by the Copenhagen School in the early 1990s, takes as its starting point the insight that security agendas are the results of political battles. The winners of security debates are successful in securitising the issue they are championing, i.e. transferring it from the sphere of normal politics to that of the politics of threat, urgency and survival. In the Copenhagen School terminology, a securitising move is to present something to an audience as an existential threat to a particular referent object and to argue that this threat must be counteracted urgently and by all means necessary. A successful 
securitisation means that the threat is placed on a prioritised 'high politics' agenda. It also involves an acceptance that the threat may be dealt with through exceptional and emergency measures - suspending ordinary procedures and rules by which action would otherwise be bound. ${ }^{11}$

The Copenhagen School suggests that securitising moves usually take the form of speech acts uttered by politically influential elites. A speech act is an utterance that also involves an action: 'by saying the words, something is done'. ${ }^{12}$ A securitising speech act presents a threat and, when successful, creates a sense of crisis and urgency which allows for exceptional and emergency measures to be taken to counteract the threat. The emphasis on elites is predicated on the assumption that a securitising speech act is far more likely to be successful if speakers hold a position of authority, power and expertise or are seen (by the audience of the securitising act) as legitimate representatives of the group for whom they speak. Thus traditional security policy elites, such as heads of state, cabinet ministers (especially foreign ministries, defence departments and homeland security), heads of intelligence agencies and defence bodies, are usually in a privileged position to speak authoritatively on security.

While analysing elite level speech acts is important for tracing the securitisation process of Zimbabwean immigration to South Africa, it is not sufficient. The elite focus means that securitisation processes are mapped primarily through studying the contestation of threat definitions. ${ }^{13}$ Little emphasis is laid on structural factors, whether discursive structures such as the inherent constraints of the concept of security, or bureaucratic or societal structures, with deep-rooted practices and power relations. Securitising moves that stray too far from linguistically, historically and socially embedded practices will struggle to succeed. And certain securitisations are promoted by bureaucracies if they confirm institutional values, advance institutional goals or confirm existing power relations (including self-preservation and advancement in competition with other institutions and bureaucracies). Thus, the Copenhagen 
School has been criticised for focusing too narrowly on the utterances of small elites, to the detriment of broader discursive, historical, social or bureaucratic processes and structures. ${ }^{14}$

Since the success of a securitising move involves its acceptance by an audience, it is necessary to determine who this significant audience is. ${ }^{15}$ In a democracy, there is a presumption that threat contestations are battled out in a public arena and that securitisations are the results of broad acceptance of threat depictions. This understanding becomes problematic in nondemocratic countries, where the threat perceptions and needs of rulers can differ widely from those of the ruled, and where the ruled may have few opportunities to make a 'securitising move'. But even in democratic countries, widespread popular fears and hatreds do not necessarily translate into a successful securitisation. A key criterion for determining if a securitising move has been successful is not only that it has been accepted by an audience, but that this audience is 'significant', meaning that it is in a position to act urgently and in emergency mode to deal with the perceived threat. In other words, the securitising move needs to translate into policy changes or changes in behaviour to urgently tackle the threat. At the national level, governments therefore remain the most central audience in need of convincing for a securitising move to become successful, since governments possess executive powers to carry out policies in security mode. ${ }^{16}$

This point seems to suggest that the Copenhagen School is right after all to pragmatically retain a statist, or rather governmental, bias in their analytical framework. However, the convoluted trajectory of the securitisation of Zimbabwean immigrants in South Africa reveals a complicated multi-level relationship between securitising actors, audiences and messages. This confirms Stritzel's assertion that 'in empirical studies one cannot always figure out clearly which audience is when and why most relevant, what implications it has if there are several audiences and when exactly an audience is "persuaded". ${ }^{17}$ Many securitisation processes can only be mapped by studying a range of securitising actors, audiences and messages, where 
securitising actors are often simultaneously audiences and where differing securitising messages can be drawn from the same securitising move.

I set out in Table 1 an analytical grid of the three significant actor groups that have been involved in the securitisation of Zimbabwean immigration, both as securitising/nonsecuritising actors and as significant audiences. They are: First, the traditional security elite, made up of government security policy makers such as the President's Office and the top foreign, security, defence and intelligence policy ministers, bureaucrats and advisers. Second, other members of the political elite, not directly related to traditional security policy making, particularly the leadership of the DHA and the police. The third group I depict as the 'grassroots level', poor South Africans living in the areas most affected by the Zimbabwean influx - the informal settlements, inner-city areas and townships. Within this broad group we find, among others, community leaders, vigilante groups, local political actors and administrators, criminal networks and gangs. Based on this division we can produce an analytical grid depicting the relationship between securitising actors and audiences and the likely outcome (successful, partially successful or weakly successful securitisations) of particular actor/audience constellations.

This article shows that securitisation can take place 'from below': grassroots level actors have the potential to become significant securitisers, even in the face of resistance from traditional security elites. Securitisation from below is a slow and messy process. As this case shows, it can also be a dangerous one, both from the perspective of state stability and the human security of immigrants. 
Table 1. Analytical grid: relationship between securitising actors and audiences

\begin{tabular}{|c|c|c|c|}
\hline Securitising actor & Government security elite & Other elite actors & Grassroots level \\
\hline \multicolumn{4}{|l|}{ Audience } \\
\hline $\begin{array}{l}\text { Government } \\
\text { security elite } \\
\text { Head of state; } \\
\text { foreign, security, } \\
\text { defence and } \\
\text { intelligence policy } \\
\text { top bureaucrats, } \\
\text { advisers and } \\
\text { politicians }\end{array}$ & $\begin{array}{l}\text { Successful securitisation. } \\
\text { Threats determined and } \\
\text { accepted by security } \\
\text { professionals and political } \\
\text { leadership. } \\
\text { The accepting audience is in } \\
\text { a position of political power } \\
\text { to enable it to instigate } \\
\text { policies in security mode. }\end{array}$ & $\begin{array}{l}\text { Successful securitisation. } \\
\text { Elite actors other than the } \\
\text { traditional security elite } \\
\text { convince the latter of the } \\
\text { existence of a threat. The } \\
\text { accepting audience is in a } \\
\text { position of power to } \\
\text { instigate policies in security } \\
\text { mode. }\end{array}$ & $\begin{array}{l}\text { Successful securitisation. } \\
\text { Grassroots actors convince } \\
\text { security elite to deal with a } \\
\text { threat in security mode. } \\
\text { Acceptance can happen } \\
\text { responsively ('accepting the } \\
\text { will of the people') or } \\
\text { reluctantly (after protest, } \\
\text { unrest, violence or threat of } \\
\text { revolt. }\end{array}$ \\
\hline $\begin{array}{l}\text { Other elite actors } \\
\text { Department of } \\
\text { Home Affairs } \\
\text { (DHA) politicians } \\
\text { and top } \\
\text { bureaucrats, police } \\
\text { and immigration } \\
\text { authorities, parts of } \\
\text { the media. }\end{array}$ & $\begin{array}{l}\text { Successful securitisation A } \\
\text { broader elite audience } \\
\text { accepts the securitisation, } \\
\text { and promotes it to members, } \\
\text { readers/listeners, thus } \\
\text { ensuring broader support of } \\
\text { government policies in } \\
\text { security mode. }\end{array}$ & $\begin{array}{l}\text { Partially successful } \\
\text { securitisation, although not } \\
\text { enough to result in state } \\
\text { policies in security mode. } \\
\text { But with strong support } \\
\text { among parts of the political } \\
\text { elite, there is a good chance } \\
\text { of momentum towards } \\
\text { broader acceptance of the } \\
\text { securitisation. }\end{array}$ & $\begin{array}{l}\text { Weakly successful } \\
\text { securitisation. Enough to } \\
\text { muster support from parts of } \\
\text { the elite, but not enough to } \\
\text { achieve decisive action to } \\
\text { respond to the threat. Success } \\
\text { depends on if these elite actors } \\
\text { induce traditional security } \\
\text { elites to instigate policies in } \\
\text { security mode. }\end{array}$ \\
\hline $\begin{array}{l}\text { Grassroots level } \\
\text { Community } \\
\text { organisations and } \\
\text { leaders; protesters, } \\
\text { demonstrators and } \\
\text { local activists; } \\
\text { vigilantes; gangs }\end{array}$ & $\begin{array}{l}\text { Successful securitisation } \\
\text { accepted/reflected in } \\
\text { popular perception and } \\
\text { mood. Broad social support } \\
\text { of the security elite's claim } \\
\text { for the need to instigate } \\
\text { security policies to deal with } \\
\text { the pronounced threat. }\end{array}$ & $\begin{array}{l}\text { Partially successful } \\
\text { securitisation. Grassroots } \\
\text { audiences accept the threat. } \\
\text { But it depends on the } \\
\text { particular political culture } \\
\text { whether grassroots } \\
\text { acceptance leads to actions } \\
\text { in security mode - by } \\
\text { grassroots actors themselves } \\
\text { or eventually by } \\
\text { governments. }\end{array}$ & $\begin{array}{l}\text { Weakly successful } \\
\text { securitisation. Broad } \\
\text { segments of the community } \\
\text { feel threatened but do not have } \\
\text { the power to influence political } \\
\text { elites. The securitisation can } \\
\text { nevertheless be successful in } \\
\text { the sense that actions take } \\
\text { place at grassroots level } \\
\text { (vigilantism, local action, etc.) }\end{array}$ \\
\hline
\end{tabular}

\section{Post-Apartheid South Africa's foreign policy discourse}

The ideas, beliefs and perceptions underpinning South Africa's post-Apartheid foreign policy

discourse can in short be characterised as a 'discourse of African solidarity'. I outline the

evolution of this discourse over the period between 1994 and 2000, in order to set the stage for

understanding the foreign policy response to the Zimbabwe crisis in the 2000s. After the

transition from Apartheid in 1994, the new ANC-led government sought to establish South

Africa as a benevolent African great power and a global emerging power. Based on the 'South

African miracle' which bestowed a sense of moral authority on the new regime, ${ }^{18}$ President 
Nelson Mandela and his foreign policy advisors outlined an activist and high-profile agenda for the African continent and beyond, promising that human rights would be the guiding light of South African foreign policy. ${ }^{19}$ By voluntarily dismantling its nuclear arsenal and spearheading the global campaign to ban landmines, South Africa set a path towards 'middle power' status, aiming to become a multilateral activist playing a key role in niche areas of international politics. $^{20}$

However, it soon became clear that South Africa's ability to punch above its weight in international arenas could not rely solely on the ethical credentials of its democratic transition. As the post-Apartheid exuberance settled, South Africa's international stature became increasingly dependent on its ability to claim the status as a dominant power in sub-Saharan Africa and speak on behalf of its African peers. But Mandela's bilateral and outspoken human rights approach had little traction in African politics. Other powerful African leaders, including Nigeria's military dictator Sani Abacha, Zimbabwe's president Robert Mugabe and Angola's president José Eduardo Dos Santos, actively resisted South African leadership on the continent. ${ }^{21}$ Disputing the legitimacy of South Africa's Africa interventions, they maintained - implied and overtly - that South Africa's transition from white minority rule was little more than window dressing, and pointed out that white officers were still leading its armed forces, white bureaucrats still developing policy in the ministries, and white economic power still underpinning South Africa's political might. ${ }^{22}$ Infamously, during a political row between Mandela and Abacha, the Nigerian information minister Walter Ofonagoro characterised South Africa as 'a white country with a black head of state' ${ }^{23}$, a comment that was deeply hurtful to the ANC but found resonance with many African leaders concerned over South Africa's ascendancy.

Lack of capacity, experience and legitimacy among its African peers led the ANC government to abandon the more forceful and explicit human rights discourse set out by Mandela. ${ }^{24} \mathrm{~A}$ more 
cautious foreign policy discourse on African solidarity, consensus and multilateralism took its place. This discourse was focused around president Thabo Mbeki's vision of an African Renaissance or renewal, ${ }^{25}$ described as the fostering of peace and stability, democratisation, good governance and sustainable development in a manner suited to African peoples' own histories and cultures. This includes a belief that African governments must work together through regional institutions to achieve the continent's rightful place in global politics. African states must also pull together to reform the global economic system into one more equitable for Africa. ${ }^{26}$ While the African Renaissance and solidarity discourse has been 'high on sentiment, low on substance, 27 , it has shaped, and continues to shape, the broad direction of South Africa's foreign policy.

One key message of this African Renaissance discourse is the affirmation - almost protestation - that South Africa is an African country, whose fate is inextricably linked to that of the rest of the continent. In 1993, Mandela asserted that 'our destiny lies with Africa, and southern Africa in particular, but [we] will cooperate in the sphere, not dominate it'. ${ }^{28}$ Mbeki stated that '[s]uch are the political imperatives of the African Renaissance which are inspired both by our painful history of recent decades and the recognition of the fact that none of our countries is an island which can isolate itself from the rest, and that none of us can truly succeed if the rest fail' ${ }^{29}$ The island motif has been frequently repeated, for instance by the then deputy minister of foreign affairs, Aziz Pahad:

\footnotetext{
'We have to accept another basic reality, namely, that South Africa cannot be an island of prosperity in a sea of poverty. Our national interest is inextricably linked to what happens in our sub-region, SADC, and the continent of Africa. Therefore, the African Renaissance is a vision that must underscore our foreign policy activities. ${ }^{30}$
}

Implicit in this reasoning is the assertion that what is good for South Africa is good for Africa, ${ }^{31}$ and that South Africa should be a key player in the continent's renewal as a primus inter pares 
among other African states. However, many other African governments remain sceptical towards this notion. To counteract accusations of self-interested economic motives driving South Africa's foreign policy, the official discourse on South Africa's connectedness to the rest of Africa is imbued throughout with an affirmation of African solidarity and repeated assertions of South Africa's humility and sense of responsibility towards the African continent. Mandela stipulated that 'the concerns and interests of the continent of Africa should be reflected in our foreign-policy choices'. ${ }^{32}$ Mbeki and his advisors developed this theme into a discourse of pan-African unity: Standing together, African countries are better able to resolve their own problems. They will also be able to assert African interests beyond the continent and finally gain an equitable role in global politics: 'Africa's time has come. The 21 st Century must be the African Century.' 33

By the end of the 1990s the notion of African solidarity had come to include the aim to make do without non-African interventions - sloganised by Mbeki as 'African solutions for Africa's problems'. ${ }^{34}$ Such self-help was depicted as an important counterweight to the marginalisation of Africa in international politics. Western powers were invited to join African countries as partners in an African-led renewal project, but in a supporting rather than guiding role. ${ }^{35}$ South Africa has been at the forefront of campaigns for reforming international institutions such as the World Trade Organisation and the UN Security Council. Mandela declared that ' $[\mathrm{t}] \mathrm{he}$ United Nations should not be dominated by a single power or group of powers, or else its legitimacy will continuously be called into question'. ${ }^{36}$ When taking office in 1999, Mbeki elevated this theme of a structurally skewed and western dominated international system to a central position in the South African government's foreign policy discourse. He repeated in numerous speeches that "the entire system of global political and economic governance [...] has to be reformed, among other things, to address the issue of equity among the nations and peoples of the world' ${ }^{37}$ Linked to this was a less overtly stated theme of the importance of the 
ANC as a national liberation movement, not only in transforming South Africa, but in exporting the domestic struggle for justice, human rights and democracy to African and global arenas. ${ }^{38}$ Thus the foreign policy discourse projects the ANC government as a pivotal actor in the efforts to transform both African states and the international system into more representative and just entities. Portraying itself as the vanguard of the African Renaissance, the ANC leadership argues that 'the $[\mathrm{ANC}]$ movement needs to continue, and deepen, its work towards the achievement of a better Africa and a better world' ${ }^{39}$

South Africa's foreign policy discourse as it evolved in the first half-decade after the end of Apartheid was partly the result of deeply held convictions and partly a strategic positioning in order to achieve acceptance on the continent as a legitimate African great power. On the one hand, it harbours an activist vision of democracy, good governance, peace and prosperity on the African continent - to make the $21^{\text {st }}$ Century the African Century. ${ }^{40}$ On the other hand, its efforts not to affront, alarm or annoy fellow African governments, has led to a rather convoluted and cautious discourse on how to achieve this vision. As Landsberg observes, 'it is one thing to preach democratization and quite another to get other states to listen' ${ }^{41}$ From Mandela's lofty human rights assertions in $1993,{ }^{42}$ the ANC government would by the year 2000 rather display an elitist version of African solidarity than criticise fellow African governments for human rights abuses or anti-democratic behaviour. South Africa's democratisation and human rights agenda had to be pursued quietly, through mediation behind closed doors, and gradually, through strengthening the AU, SADC and other regional institutions. Asserting the need to defend African sovereignty against international interventionism, South Africa distanced itself from western powers. The motivation underlying this discourse was straight-forward: South Africa could only pursue its ambition to be an emerging power in global politics if it were widely perceived as representing the African continent. This in turn meant that South Africa required the acceptance of fellow African leaders that it was a truly African power rather than 
a mouthpiece of the West or a vestige of colonialism and white domination. The need to be accepted by its African peers led South Africa's foreign policy discourse to display elements of both leadership and humility. ${ }^{43}$

\section{South Africa's immigration discourse}

At the same time as the ANC government's foreign policy discourse relied on concepts of African solidarity and renaissance, a very different domestic discourse was constructed on the issue of African immigration, confirming the perception that African solidarity is the prerogative of the continent's political elites. Always a 'region on the move' ${ }^{44}$, southern Africa has witnessed centuries of great movements of people fleeing war and violence or seeking economic opportunities. In modern history, a vast but tightly controlled system of organised labour migration to South Africa's mining and agricultural industry was put in place by colonial authorities and later expanded by the Apartheid regime. ${ }^{45}$ Millions of southern African labourers were allowed in when needed, closely monitored while in the country, and peremptorily repatriated when no longer required.

As South Africa's townships erupted into 'ungovernability' from the mid-1970s onwards, the Apartheid authorities' ability to enforce draconian pass laws and immigration rules became increasingly feeble. ${ }^{46}$ As Apartheid was dismantled in 1994, significant numbers of undocumented African immigrants resided in South Africa. Faced with high unemployment figures, the ANC-led government put in place a new immigration regime to control and reduce the influx, making it almost impossible for African immigrants to obtain work permits and legal residency. But South Africa's long and permeable borders, the economic disparity between South Africa and its neighbours, the relative ease of finding informal employment (e.g. in agriculture or domestic work), and the existence of well-established migration routes, combined to allow unprecedented levels of undocumented immigration. The most visible 
aspect of this modern migration has been the explosion in the number of asylum seekers, filling the ranks of South Africa's asylum queue with nationals of 89 different countries. ${ }^{47}$

Human Rights Watch wrote already in 1998 that 'South Africa's public culture has become increasingly xenophobic' ${ }^{48}$ Apartheid South Africa's insulation from the rest of Africa resulted in a self-image of exceptionalism and superiority, combined with a sense of being under siege. Democratic South Africa in many ways retained this siege mentality. Many black and white South Africans share a view of the rest of the continent as less advanced, and worry about the African backward 'other'. ${ }^{49}$ This has led to the framing of immigration as a traditional security discourse of 'us' versus 'them', where the threatening other are African immigrants and the threat is depicted as a toxic mix of criminality, disease, job stealing and scrounging on the welfare system. ${ }^{50}$ The perceived victims of this threat are particularly the marginalised and jobless urban poor. African immigrants have come to function as scapegoats for the many socio-economic ills afflicting townships, informal settlements and inner-city areas.

Xenophobia and autochthony (a 'sons of the soil' mentality) has been on the rise over the past couple of decades, not only in South Africa, but in many parts of Africa. ${ }^{51}$ South Africa's antiimmigrant xenophobic discourse has in particular been driven by the DHA. Chief Mangosuthu Buthelezi, Minister of Home Affairs from 1994 to 2004, was deeply hostile to African immigrants. ${ }^{52} \mathrm{He}$ posited 'illegal immigration' as the most important threat facing South Africa, warranting draconian counter-measures. His views bolstered widespread xenophobic sentiments within South African society, media and the political establishment. ${ }^{53}$

The anti-immigrant xenophobic discourse centred in particular on crime, although welfare scrounging ${ }^{54}$, the spread of disease,${ }^{55}$ and job stealing also figured prominently. Even Mbeki, in an unusual outburst while Vice-President, was quoted in the Malawian newspaper as saying: 'Our people are just loafing in the streets at the expense of foreigners flooding our offices and 
mines. The Home Affairs Ministry will have to sort this thing out [. . .] these foreigners have to go back home' ${ }^{56}$ In 1997, the then Defence Minister Joe Modise blamed high crime rates on immigrants, complaining 'what can we do? We have one million illegal immigrants in our country who commit crimes' ${ }^{57}$ Police, migration authorities and parts of the media shared the unsubstantiated assumption that 'illegal' migrants were the main cause of the country's dismal crime figures. ${ }^{58}$ Research into the relationship between immigrants and crime does not show migrants to be less law abiding than South Africans. ${ }^{59}$ Yet the then Director-General of Home Affairs, Billy Masetlha, misleadingly claimed in 2002 that:

\footnotetext{
Approximately 90 per cent of foreign persons who are in RSA with fraudulent documents, i.e., either citizenship or migration documents, are involved in other crimes as well (...) it is quicker to charge these criminals for their false documentation and then to deport them than to pursue the long route in respect of the other crimes that are committed. ${ }^{60}$
}

The criminalising and xenophobic discourse on African immigration was accompanied by a securitised Apartheid era-style paramilitary police practice of 'controlling' undocumented migration through massive night-time raids on urban areas; scooping up, arresting and deporting anyone without papers. ${ }^{61}$ Such police practices confirmed and reinforced the images presented by the xenophobic discourse of immigrants as threatening, intruding aliens against whom it was justified to use violence and force. In this sense, the xenophobic discourse was a successful 'securitising move', in the Copenhagen School terminology, legitimising actions in emergency mode. Both discourse and police practice had broad resonance among the population: In 1997, 48 percent of South Africans surveyed felt that African immigrants were a 'criminal threat'; 37 percent perceived them as threatening jobs and the economy, while 29 percent believed they brought diseases into the country. ${ }^{62}$ The anti-foreigner discourse made no attempt at discerning undocumented migrants from those in the country legally, lumping everybody together in the term 'illegal alien'. ${ }^{63}$

Returning to the analytical grid of the relationship between securitising actors and audiences set out earlier, it is noteworthy that South Africa's traditional security policy elite - the 
presidency and the foreign, defence and intelligence community - had little input into this securitisation discourse. Instead, a lower tier of South Africa's political elite, particularly the DHA, were its main propagators. ${ }^{64}$ This discourse, and the police practices accompanying it, then found resonance among the urban poor, frustrated with lack of jobs, housing, and opportunity. The xenophobic discourse and brutal police conduct against immigrants created a permissive environment within which an otherwise disempowered part of the population could vent their anger, resentment, frustration and fear on a group even more vulnerable than itself. ${ }^{65}$

Thus, in the period 1994-2000, the securitisation of African immigration took place as a negotiation between 'second-tier' elite securitisers within Home Affairs and the police and a responsive grassroots audience (although it should be made clear that far from all township dwellers were xenophobic). At the same time, the traditional security policy elite displayed little interest in migration issues and, with few exceptions, did not opt into the Home Affairs xenophobic discourse. Instead, it subsumed the immigration challenge under the logic of the foreign policy discourse of African solidarity: the influx of fellow Africans was a burden South Africa would have to shoulder due to the obligations conferred on South Africa by its great power status and the long history of injustice inflicted by the Apartheid regime on the region.

\section{The South African response to the Zimbabwe crisis}

This article is not concerned with the causes of the political and economic debacle that has engulfed Zimbabwe for over a decade, but with how the ensuing mass Zimbabwean exodus has affected both South Africa's domestic immigration policy and its strategy for dealing with the situation next door. The remainder of this article depicts the competition between the logics of the Home Affairs xenophobic discourse, which has resonated strongly at grassroots level, and the foreign policy African solidarity discourse, promoted by South Africa's most powerful political elite, in influencing South Africa's response to the Zimbabwe crisis. From the point 
of view of securitisation theory, the process of securitisation of Zimbabwean immigration has been unorthodox in that it has been pushed from below, and resisted from above.

\section{South Africa's foreign policy goals towards Zimbabwe}

South Africa's foreign policy aims towards Zimbabwe have been characterised as perplexing even by veteran analysts. ${ }^{66}$ As summed up by Garth le Pere, "“quiet diplomacy" in Zimbabwe and [the] May 2008 xenophobic violence have challenged South Africa's international legitimacy as a moral leader of the Global South'. ${ }^{67}$ However, when viewed within the context of the foreign policy discourse on African solidarity, its Zimbabwe approach becomes more explicable. South Africa's foreign policy objectives are not merely to restore and strengthen democracy in Zimbabwe and reduce the influx of Zimbabweans onto its own soil. A more pressing concern for the ANC government has been how its handling of the Zimbabwe crisis affects its standing among other African governments.

Infused with themes of racism and neocolonialism, the Zimbabwe debacle put to the test the ANC government's core aim to establish South Africa as a truly African power, not a proxy for Western interests. Previously stung by Mugabe's and other African leaders' suggestions that South Africa may not have the interests of Africa at heart, ${ }^{68}$ it painstakingly avoided a response to the Zimbabwe crisis that could be construed as dictated by its own white minority or the former colonial power, Britain. ${ }^{69}$ Thus the international controversy around Zimbabwe contributed to radicalising South Africa's African solidarity foreign policy discourse. The ANC government's vocal defence of the sanctity of national sovereignty against western interventions took on a stronger hue in the 2000s. ${ }^{70}$ This was partly due to the more ideological foreign policy outlook of Mbeki compared to Mandela; partly a reaction to the American led War on Terror; and partly a result of what many South Africans perceived as disproportionate (and implicitly racist) western concern with the fate of white landowners in Zimbabwe. The anti-intervention theme already existed in the foreign policy discourse in the 1990s, but South 
Africa's preference for quiet and non-coercive diplomacy took on a dogmatic tint in the case of Zimbabwe. As western denunciation of ZANU-PF intensified, the ANC government's inclination to understand African sovereignty as regime security became particularly pronounced in the case of Zimbabwe. ${ }^{71}$

In Zimbabwe, not only regime security but the security of a fellow ruling party of national liberation, was at stake. Liberation credentials still matter to the $\mathrm{ANC},{ }^{72}$ and nowhere has this been more tangible than in its Zimbabwe diplomacy. In 2001 South Africa's then president, Thabo Mbeki, wrote a long treatise entitled 'How Will Zimbabwe Defeat its Enemies?', addressed to the leadership of ZANU-PF but also circulated among ANC party members. While criticising many ZANU actions as counter-productive, including the land-grabbing by war-veterans and political violence against the opposition, the treatise revealed an inability to envision any other party ruling Zimbabwe than 'the party of revolution', ZANU-PF. ${ }^{73}$ Parts of the treatise conflate 'the people of Zimbabwe' with ZANU. Other parts acknowledge that ZANU has lost support among large parts of the Zimbabwean population, but argues this is because opposition voters have been misled: The opposition has seemingly taken over the defence of the democratic project, but is actually controlled by neo-colonial forces, within and outside Zimbabwe, opposed to the national democratic revolution. ${ }^{74}$ The treatise, together with South Africa's actual mediation efforts and reluctance to criticise or otherwise undermine ZANU-PF, reveal a strong reluctance to envision the MDC taking office: democracy in Zimbabwe is desirable, but only if led by ZANU-PF. Although South Africa's government would like to see a democratic, economically prosperous and stable Zimbabwe, the aims of its power-broking efforts have been to help ZANU-PF regain legitimacy rather than merely to ensure democratic restoration. Such an outcome would be in the interest of many of the SADC region's governments, who as 'brother presidents in sister parties' ${ }^{95}$ share ZANU-PF's history as liberation movements. 


\section{South Africa's response to the Zimbabwean influx}

The 2000s saw a decrease in overtly xenophobic statements uttered by Home Affairs and immigration authorities. This partly resulted from minister Buthelezi leaving office in 2004 and partly from ANC concern over growing xenophobic violence. For instance, the resolutions from the ANC's important 52 $2^{\text {nd }}$ National Conference in Polokwane in 2007 stated that 'ANC structures must take a lead in fighting xenophobic practices' and 'acknowledge the valuable skills many immigrants bring to the country'. On the other hand, the same document introduced its section on 'Immigration and Refugees' by cautioning that immigration control poses 'a challenge to the state' and that revisions to the Immigration Act should ensure that 'national and regional security concerns are addressed'. Since the document did not specify what such security concerns might be it did little to dispel the view that migrants themselves constitute a threat to South Africans. ${ }^{76}$

While the Home Affairs xenophobic discourse was toned down, the securitised and criminalising police response to immigration continued unabated. The Home Affairs xenophobic discourse had contributed to setting the stage for a lawless environment for African immigrants and the neighbourhoods in which they lived: 'Criminals, along with the police [...] learned to exploit foreigners' vulnerabilities' and as a result immigrants became disproportionately victims of criminal attacks. ${ }^{77}$ The rise in xenophobic violence, together with police harassment, detention and deportation, left African immigrants feeling profoundly insecure in their host country. South Africa had, by the time the influx of Zimbabweans gathered pace in the early $2000 \mathrm{~s}$, '[i]nstitutionalised attitudes and practices that dehumanise foreign nationals and/or minority groups and exclude them from access to social protection and rights'. A 'culture of impunity' had been entrenched 'with regard to public violence in general and xenophobic violence in particular that encourages the ill intentioned to attack nonnationals'. 78 
Township dwellers seemingly responded more readily to the continued high-visibility police securitisation of immigrants than to the government's much less visible and ambivalent (as shown by the example from the 2007 Polokwane resolutions above) effort to tone down verbal attacks on immigrants. Thus grassroots level securitisations of African immigration particularly the Zimbabwean influx - gathered pace in the 2000s. A survey on attitudes showed a steep rise in anti-immigrant sentiments from 1999 to 2006, with 35 (up from 25) percent of respondents favouring a total ban on immigration. Of those asked, only 12 percent had favourable views of Zimbabweans. ${ }^{79}$ The perception of immigrants as threats became more pervasive: in 2006, a majority of respondents agreed that migrants used up resources intended for South Africans (67\%), committed crime (67\%), took jobs away from South Africans (62\%) and brought disease into the country $(49 \%){ }^{80}$

Concentrating on the response to Zimbabwean immigration, the official approach to this influx was contradictory. At the level of discourse, xenophobic statements were to some degree replaced by a 'non-discourse' of benign neglect preferred by the Presidency and foreign affairs officials. Mbeki displayed this laissez-faire view in one of his few comments on Zimbabwean immigration:

As to this... inflow of illegal people, I personally think that it's something we have to live with... it's difficult; you can't put a Great Wall of China between South Africa and Zimbabwe to stop people walking across." ${ }^{\prime 1}$

But little was done by the political elite to counteract widespread perceptions of fear and hostility towards foreigners among the populace. And at the level of immigration policy (rather than discourse), Zimbabwean immigrants were handled as a criminal invasion force that needed to be repulsed. Zimbabweans were treated as a group of illegal aliens eager to partake in South Africa's relative riches of jobs and opportunity. The possibility that Zimbabweans might have protection needs was dismissed. ${ }^{82}$ DHA repeatedly declared that 'Zimbabweans are here to work'. Official asylum statistics reveal a near-zero refugee recognition rate for Zimbabwean 
asylum seekers. An unpublished recent review of asylum decisions made by the SADC office in one South African Refugee Reception Centre showed that of 15,000 asylum applications, only one was approved. ${ }^{83}$ This compares unfavourably to global recognition rates. ${ }^{84}$

The main policy tool employed to 'repulse' the Zimbabwean immigration flow was detention and deportation. 17,000 Zimbabweans were deported in 2001, 72,000 in 2004, ${ }^{85}$ and 300,000 in 2008, despite the acknowledgement by Home Affairs officials that deportations did little to reduce the number of Zimbabweans in South Africa. ${ }^{86}$ Dropped off at the Zimbabwean side of the Beit Bridge border, many deportees simply turned around and headed back into South Africa, either by fording the Limpopo river or by bribing their way past corrupt border officials. Thus the official immigration policy response to the Zimbabwean influx was muddled: partpermissive, part-criminalising. The result was that most Zimbabweans, although portrayed as opportunistic illegal economic migrants, were able to stay and work in South Africa and remit money to increasingly desperate family members back home.

This attitude of benign neglect from the foreign and security policy elite coupled with harassment, deportations and cursory rejections of asylum applications at the administrative level fit well with the ANC government's foreign policy priorities of African solidarity and quiet diplomacy towards Zimbabwe. By broadly tolerating Zimbabwean migrants, South Africa became an economic and political safety valve for the Zimbabwean regime. Remittances from migrants contributed to Zimbabwe's economy and helped ordinary Zimbabweans survive. Politically, it was helpful for ZANU-PF that many opposition supporters and activists were exiled. As the main SADC mediator between ZANU-PF and the MDC, South Africa never brought up, or included, the diaspora when discussing voting rights in Zimbabwean elections despite the fact that a 'voter drain' of maybe one million (largely opposition) voters would affect election outcomes. 
The quiet diplomacy strategy made it essential for the ANC government to down-play the political dimension of Zimbabwean flight, as seen in the near-zero refugee recognition rate of Zimbabwean asylum seekers. Thus South Africa's immigration approach could not be construed as a criticism of ZANU-PF or an acknowledgment of opposition grievances. The choice of approach was not politically neutral: it avoided adding legitimacy to the MDC's cause. The asylum approach also supported South Africa's strong commitment to national sovereignty. By not granting asylum to Zimbabweans, South Africa avoided indirectly criticising the internal politics of a sovereign country. Up until 2008 the twice-weekly deportation trains to the Beit Bridge border were a constant signal that South African authorities did not consider the Zimbabwe crisis to be much of a crisis at all.

\section{Humanitarian disaster, xenophobic riots and a foreign policy shift}

2008 was a watershed both within Zimbabwe and for the ANC government's foreign and migration policy response to the Zimbabwe crisis. Within Zimbabwe, the situation reached a low point, with violent and rigged elections, hyperinflation, internal displacement, food shortages and a cholera outbreak. At the same time, South Africa's economy was slowing. As a humanitarian emergency developed in Zimbabwe, Zimbabweans grew more desperate to enter South Africa but were less welcome on their arrival. Xenophobic violence became widespread and detention and deportation efforts were stepped up. ${ }^{87}$ In May that year, xenophobic riots started in the Alexandra township of Johannesburg and quickly spread across South Africa. As Zimbabweans and other foreign nationals flocked into temporary IDP camps, or to the Refugee Reception Centres to seek the relative protection granted the owner of an asylum seekers permit, South Africa became the world's number one asylum destination. ${ }^{88}$ Order was only restored through large-scale military deployment in the worst-affected townships and settlements. The shame and soul searching following the riots was palpable. In an effort to stop the violence, Archbishop Desmond Tutu declared that ' $[\mathrm{t}]$ he world is shocked 
and is going to laugh at us and mock us. We are disgracing our struggle heroes. Our children will condemn us in the future'. ${ }^{89}$ President Mbeki declared South Africa 'disgraced' and national papers announced this as 'arguably the most grave, dark and repulsive moment in the life of our young nation' ${ }^{90}$

This combination of humanitarian crisis inside Zimbabwe, cholera spreading across the border, and shock over the xenophobic riots, jolted the government foreign and security policy elite, particularly in the President's Office, out of its complacent attitude of benign neglect towards the Zimbabwean influx. A change in policy approach was instituted both towards Zimbabwean immigrants and towards the ZANU-PF regime. While not a u-turn, this approach was more activist and energetic, more sympathetic to the plight of ordinary Zimbabweans, and less sympathetic to the ZANU-PF regime. The era of benign neglect was over.

First, in the area of immigration policy, South Africa introduced for the first time a specific regime for Zimbabweans, including automatic 90-day visa-free entry, a moratorium on deportations and a 'special dispensation' that would allow all Zimbabweans to live, work, receive schooling and healthcare for a 6-month period in South Africa. The humanitarian disaster in Zimbabwe encouraged agreement among the relevant government departments (DHA, the Department for International Relations and Cooperation (DIRCO), and the President's Office) on the moratorium on deportations as a 'humanitarian policy'. It is less clear if the special dispensation as such had widespread government support. The Home Affairs minister left office only weeks after announcing it, and her successor, Nkozasana DlaminiZuma, never implemented it. As a result, the new policy from April 2009 entailed a moratorium on deportations, but did not regularise Zimbabweans' stay in South Africa. The ensuing uncertainty meant that pressure on the asylum system continued to rise. New Zimbabwean applications rose from 122,600 in 2008 to 149,453 in $2009 .{ }^{91}$ A new initiative launched in 
September 2011, the Zimbabwean Documentation Process, also left the majority of Zimbabwean immigrants unregistered.

The new policy had three effects: First, it relieved the humanitarian situation within Zimbabwe by allowing remittances to flow freely. Second, it helped control the cholera epidemic, since cholera victims present in South Africa no longer felt forced to hide in fear of deportation. Third, it sent a signal to the South African population, for the first time, of a sense of solidarity with ordinary Zimbabweans rather than exclusively with the Zimbabwean regime. Thus, it was a first step towards counteracting the prevailing securitising discourse of Zimbabweans as just another group of opportunistic 'African others' posing a threat to the jobs, health and safety of South African citizens. For instance, in June 2008, the then Labour minister, Membathisi Mdladlana, declared it 'a misconception to conclude that migrants steal jobs from South Africans. The opposite is actually true.' He continued, '[i]n the last two months we have our people being easily misled into believing that their genuine concerns on poverty and unemployment are caused by our fellow brothers and sisters from Africa. ${ }^{92}$ Such comments aside, the shift was a matter of degree rather than wholesale change. The policy of routine refusal to grant asylum to Zimbabweans continued, and the asylum determination system remained riddled with problems of corruption and poor capacity. ${ }^{93}$

Second, there was also a shift in foreign policy. The xenophobic riots and unrest in South Africa, worsening political violence against opposition supporters in Zimbabwe, and the influx into South Africa of victims of Zimbabwe's humanitarian emergency, all contributed to a marked change in the ANC government's mediation efforts. Unprecedentedly, ANC officials began to openly criticise their ZANU-PF counterparts. Soon after the xenophobic riots started, Pallo Jordan, member of the ANC's National Executive Committee (NEC), wrote in a commentary: 
If ZANU (PF) has lost the confidence of a substantial number of the citizens of that country, such that the only means by which it can win elections is either by intimidating the people or otherwise rigging them, it has only itself to blame. Nobody doubts the anti-imperialist credentials of ZANU (PF), but that cannot be sufficient reason to support it if it is misgoverning Zimbabwe and brutalising the people. ${ }^{94}$

A month later, on 24 June 2008, President Zuma stated at a press conference in Johannesburg that "[w]e cannot agree with ZANU-PF. We cannot agree with them on values [...]. We fought for the right of people to vote, we fought for democracy." 95 The ANC party released a statement the same day declaring that it was 'deeply dismayed by the actions of the government of Zimbabwe, which is riding roughshod over the hard-won democratic rights of the people of that country'. ${ }^{96}$ Later that year the ANC Secretary-General Gwede Mantashe stated that abduction and detention without trial in Zimbabwe 'tests the very fabric of the liberation we fought for in this region of Africa'. ${ }^{97}$

The hard talk was followed by heavy diplomatic pressure on both ZANU-PF and opposition MDC politicians to force through a transition coalition government in Zimbabwe. The Global Political Agreement (GPA) left President Mugabe at the helm but created the position of Prime Minister for MDC-leader Morgan Tsvangirai. The GPA was a typical creature of South African diplomacy: a government of national unity dominated by the previously ruling party, ZANUPF. As such it was far from a return to democracy, but it reduced political violence within Zimbabwe, allowed its economy to stabilise, and mitigated the influx into South Africa. The moratorium on deportations supported South Africa's efforts to make this coalition work: Economically, it eased the strain on Zimbabwe's economy by not hampering the flow of remittances. Politically, with the moratorium in place, there would be no sudden mass return of exiled Zimbabwean opposition sympathisers with the potential to destabilise the fragile compromise between ZANU-PF and the MDC.

\section{Conclusion: securitisation from below and its impact}

This article has aimed to show that South Africa's immigration and foreign policies towards Zimbabwe are best understood when analysed together, and within a securitisation framework. 
The pushing through of the GPA should be understood as the result of an uneasy compromise between domestic and foreign policy concerns. I will conclude by summing up the nature of this compromise and the role 'securitisation from below' played in amending South Africa's foreign policy approach from mid-2008 onwards. This done, I use the findings from this study of the complex relationship between securitising actors and audiences to suggest some avenues for further exploration within securitisation theory.

For most of the 2000s, the official approach to the Zimbabwean immigration crisis was one of 'benign neglect', ignoring widespread resentment and fear within South Africa towards immigrants in order to pursue a foreign policy strategy of (elite) African solidarity and quiet diplomacy towards the Zimbabwean regime. This policy was driven by the foreign and security policy elite, especially in the President's office. It can be described as a 'non-securitising' silence more than a desecuritising discourse, since there were few attempts at counteracting anti-immigrant sentiments displayed by other parts of the political elite and at grassroots level. Existing alongside this non-securitising silence was the xenophobic Home Affairs discourse. Although this discourse was slightly dampened in the 2000s, immigration authorities and the police maintained a high level of harassment of Zimbabweans in South Africa, thus continuing to send out the message to the South African populace that Zimbabweans were not welcome. Harassment aside, the overall approach of benign neglect emanating from the highest echelons of power in South Africa ensured that most Zimbabweans were allowed to enter, stay, work, and send money to their family back home in Zimbabwe.

The Home Affairs xenophobic discourse had strong resonance at grassroots level, and it was in the townships and informal settlements that the securitisation of Zimbabwean immigration increased in intensity. Xenophobic violence, vigilantism and public protests against poor service delivery increased over the course of the 2000s, and the riots of May 2008 raised the spectre of the 'ungovernable' townships of the 1980s. Interviews with township dwellers after 
the riots depicted not only resentment against foreigners, but a sense of marginalisation and alienation vis-a-vis the government:

Government is fighting against us, employers are fighting against us, and foreigners are fighting against us. That is why we fight against them (foreigners), because they are nearer. They don't support us in our struggle..$^{98}$

African immigrants, and Zimbabweans in particular, were the easiest immediate target of this venting of anger, but the securitisation of immigration was part of a broader breakdown of trust in the authorities and a sense that township dwellers must fend for themselves.

As Balzacq argues, 'the success of securitisation is contingent upon a perceptive environment' ${ }^{99}$ In this case the traditional security elite can be described as the significant audience for grassroots level securitisation attempts: Initially this elite audience was not responsive to securitisation from below, but as grassroots level actions in security mode became more widespread and challenging to elite authority, the environment for the securitisation of Zimbabwean immigration became more conducive. This resulted in the securitisation becoming partially successful in that it contributed to changing the direction and vigour of the government's mediation efforts in Zimbabwe. After almost a decade of no movement in the negotiations between the parties, the South African mediation team forced through the GPA in a short spate of time.

The securitisation from below of Zimbabwean immigration was nevertheless only partially successful. It has contributed to shaping both South African foreign and immigration policy since 2008. However, South Africa's current Zimbabwe policy reflects an uneasy compromise between domestic pressure and foreign policy aims. As argued by Jordaan, if made to choose, South Africa prefers stability over democracy and incumbents over opposition groups in its African foreign policy. ${ }^{100}$ In Zimbabwe, this has involved finding ways in which South Africa could help defuse and placate opposition movements rather than support their ambitions to take 
power. Critics argue that the GPA coalition government has co-opted MDC politicians into ministerial positions without allowing broader reform of Zimbabwean politics or challenged ZANU-PF's hold on this politics. ${ }^{101}$

A way to aid this outcome of 'controlled democracy' in Zimbabwe is to ensure that the opposition-dominated diaspora in South Africa does not return too soon or in too disorderly a manner. The 'brain drain' from Zimbabwe is also a voter drain. Although constitutional reform and free and fair elections are central elements of the GPA, neither ZANU-PF nor the South African mediation team have opened the door for including the diaspora in consultations over constitutional reform.

In terms of theoretical findings, this study highlights the importance of studying securitisation processes as a series of shifting relationships between several significant audience and actor groups. Analysis should never proceed on the assumption that securitisation processes are driven by political elites, but should be conducted across layers of securitising actors and audiences at different levels of power and influence. In the case of South Africa, while each group responded to securitisation and non-securitisation attempts of the other groups, a gradual process of securitisation from below eventually led to the grassroots 'being heard' despite their marginal position in national politics. But it was the violent response in the form of riots and vigilantism, not the persuasive nature of their argument casting immigrants as threats, that led the foreign and security policy elite to respond. Thus, the securitisation from below was 'successful' only when it in turn became securitised by the government as a potential threat to domestic stability, rule of law and state monopoly on violence. The response from the elite was not to clamp down on immigrants and chase them out of South Africa's townships. After all, the detention and deportation policy pursued for over a decade had proven both ineffectual and highly problematic from the point of view of the country's liberal constitution and international reputation. Instead the response was an attempt to control immigration numbers through 
improving conditions in the sending country, Zimbabwe, while publicly declaring the riots as shameful 'criminal acts against our African brothers and sisters'. 102 'Successful' or partially successful securitisation does not, then, necessarily involve acceptance by the elite of the rationale behind the securitising move. In this case, government action to control Zimbabwean immigration numbers was one of several measures aimed at curbing the spread of vigilante groups and xenophobic violence, rather than proof of the acceptance of the claim that Zimbabwean immigrants constituted a national threat. This distinction between 'success' and 'accept' is important for our understanding of how battles for securitisation takes place in the political sphere.

Another theoretical insight offered by this study of 'securitisation from below' is that securitising acts need not be speech acts, and that non-verbal acts should be included in our study of securitisation processes. The urban poor have little voice in South African politics. Instead, other forms of symbolic securitising acts were utilised, particularly violence. Williams and Hansen have both highlighted the importance of including the role of images in securitisation processes. ${ }^{103}$ In South Africa, one such potent image was the use of 'necklacing' in the murder of African immigrants during the xenophobic riots. ${ }^{104}$ This symbolic securitising act pointed back to the anti-Apartheid struggle of the 1980s when this horrific practice was used against suspected police informers.

Several questions arise from this study, both regarding the future of Zimbabweans in South Africa and the situation within Zimbabwe. The uneasy compromise that ensued between immigration and foreign policy has persisted since 2008. It has led to some improvements for Zimbabweans in South Africa, with opportunities (at least for some) to regularise their stay and the moratorium on deportations kept in place. It has also led to a more robust attitude towards ZANU-PF to ensure that the GPA survives and Zimbabwe does not again descend into violence and economic chaos on a scale leading to another surge in the arrival of destitute Zimbabweans 
in South Africa, as happened in 2008. ${ }^{105}$ On the other hand, although more pressure has been brought to bear on ZANU-PF, quiet diplomacy and African solidarity continues to guide South Africa's response to the Zimbabwe crisis. The ANC government seldom acknowledges the political, not only the economic, nature of the Zimbabwean exodus, and has done little to counteract the image of Zimbabweans as opportunistic job stealers. As a result, xenophobic attacks remain common. Although the 2008 riots have been thoroughly debated in the South African public sphere, it is not clear that this debate has been conducted in terms understood or accepted among the urban poor.

In South Africa, the grassroots securitisation of Zimbabwean immigration had to turn extremely violent, creating widespread public disorder, in order to achieve some form of recognition by those with the power to affect policy. This undermined the human security of immigrants, sound community relations and even the legitimacy of state authority. By using a negligent attitude to Zimbabwean immigration as a foreign policy tool, the government fuelled an already ripe xenophobic atmosphere. The current compromise between foreign policy and domestic security concerns remains fragile and will be severely tested when new elections in Zimbabwe, scheduled for 2012, are likely to cause renewed tension and violence within Zimbabwe, which again may lead to a new surge of Zimbabweans crossing the Limpopo river into South Africa.

\section{Acknowledgments}

My warmest appreciation to Ruth Blakeley, Hugh Miall, Adam Roberts, Elizabeth Sidiropolous and three anonymous referees for providing valuable comments at various stages of the writing of this article. I am grateful to the Economic and Social Research Council (ESRC) for providing the funds for field research in South Africa and to the South African 
Institute of International Affairs (SAIIA) for providing institutional support during my stay there.

\section{Reference List}

Adebajo, Adekeye, Adebayo Adedeji and Chris Landsberg (eds.), 2007. South Africa in Africa: The Post-Apartheid Era. University of KwaZulu-Natal Press, Scottsville.

Alden, Chris, and Garth le Pere, 2003. South Africa's Post-apartheid Foreign Policy: From Reconciliation to Revival? Adelphi Paper 362. IISS, London.

Alden, Chris and Maxi Schoeman, 2003. 'The Hegemon That Wasn't: South Africa's Foreign Policy Towards Zimbabwe'. Strategic Review for Southern Africa 25(1), May, 1-28.

Alden, Chris and Mills Soko, 2005. 'South Africa's Economic Relations with Africa: Hegemony and its Discontent'. Journal of Modern African Studies 43(3), 367-392.

ANC, 2007. 52 ${ }^{\text {nd }}$ National Conference: Resolutions. ANC, 20 December.

ANC, 2008. 'Statement of the National Executive Committee on the Occasion of the $96^{\text {th }}$ Anniversary of the ANC'. ANC, 8 January, Johannesburg.

Baldwin, David, 1997. 'The Concept of Security'. Review of International Studies 23(1), 5-26.

Balzacq, Thierry, 2005. 'The Three Faces of Securitization: Political Agency, Audience and Context'. European Journal of International Relations 11(2), 171-201.

Barber, James, 2004. Mandela's World. James Currey, Oxford.

Barber, James, 2005. 'The New South Africa's Foreign Policy: Principles and Practice', International Affairs 81(5), 1079-1096. 
Bigo, Didier, 2002 'Security and Immigration: Towards a Critique of the Governmentality of Unease', Alternatives 27, 63-92.

Bigo, Didier, 2005. 'From Foreigners to "Abnormal Aliens": How the Faces of the Enemy Have Changed Following September the $11^{\text {th }}$. In International Migration and Security: Opportunities and Challenges, eds. Elspeth Guild and Joanne van Selm. Routledge, Abingdon.

Buzan, Barry, Ole Wæver and Jaap de Wilde, 1998. Security: A New Framework for Analysis. Lynne Rienner Publishers, London.

Bøås, Morten, 2009. "New” Nationalism and Autochthony - Tales of Origin as Political Cleavage'. Africa Spectrum 44(1), 19-38.

Chirwa, Wiseman Chijere, 1998. 'Aliens and AIDS in Southern Africa: The Malawi-South Africa Debate'. African Affairs 97(386), 53-79.

Crisp, Jeff and Esther Kiragu, 2010. Refugee Protection and International Migration: A Review of UNHCR's Role in Malawi, Mozambique and South Africa. Geneva: UNHCR Policy Development and Evaluation Service (PDES). UNHCR Doc. No. PDES/2010/10, August.

Crush, Jonathan, 2000. 'The Dark Side of Democracy: Immigration, Xenophobia and Human Rights in South Africa'. International Migration 38(6), 103-133.

Crush, Jonathan (ed.), 2008. The Perfect Storm: Xenophobia in Contemporary South Africa. The Institute for Democracy in South Africa (IDASA), Johannesburg.

Crush, Jonathan, Vincent Williams and Sally Peberdy, 2005. Migration in Southern Africa: A Paper Prepared for the Policy Analysis and Research Programme of the Global 
Commission on International Migration. Global Commission on International Migration, September.

Danso, Ransford and David A. McDonald, 2001. 'Writing Xenophobia: Immigration and the Print Media in Post-apartheid South Africa'. Africa Today 48(3), Fall, 115-137.

Department of Foreign Affairs (DFA), 2009. South Africa in the United Nations Security Council (2007-2008). DFA, Pretoria.

Dodson, Belinda, 2010. 'Locating Xenophobia: Debate, Discourse and Everyday Experience in Cape Town, South Africa'. Africa Today 56(3), 2-22.

Doyle, Lisa, 2009. "I Hate Being Idle”: Wasted Skills and Enforced Dependence among Zimbabwean Asylum Seekers in the UK. British Refugee Council, London, July.

FMSP (Forced Migration Studies Programme), 2008. 'Zimbabwe and South Africa's International Reputation'. Background Brief, South African Futures-Zimbabwean Futures Forum. FMSP, University of Witwatersrand, Johannesburg.

Givens, Terri, Gary Freeman and David Leal, 2009. Immigration Policy and Security: US, European, and Commonwealth Perspectives. Routledge, Abingdon.

Government of South Africa, 2010. Report on 2009 Asylum Statistics. Government of South Africa, South Africa.

Guild, Elspeth, 2003. 'Editorial of Special Issue on 9/11 and Migration'. European Journal of Migration and Law 4(4), 395-8.

Guild, Elspeth and Joanne van Selm, 2005. International Migration and Security: Opportunities and Challenges. Routledge, Abingdon. 
Habib, Adam, 2009. 'South Africa's Foreign Policy: Hegemonic Aspirations, Neo-liberal Orientations and Global Transformation'. South African Journal of International Affairs 16(2), 143-159.

Hamill, James and John Hoffman, 2009. 'Quiet Diplomacy or Appeasement? South African Policy towards Zimbabwe'. The Round Table 98(402), June, 373-384.

Hammerstad, Anne, 2005. 'Domestic Threats, Regional Solutions? The Challenge of Regional Security Integration in Southern Africa'. Review of International Studies 31(1), 69-87.

Hansen, Lene, 2011. 'Theorizing the Image for Security Studies: Visual Securitization and the Muhammad Cartoon Crisis'. European Journal of International Relations 17(1), 5174.

Human Rights Watch, 1998. Prohibited Persons: Abuse of Undocumented Migrants, Asylum Seekers, and Refugees in South Africa. HRW, New York.

Human Rights Watch, 2009. 'South Africa Country Summary'. World Report 2009: Events of 2008. HRW, New York.

Human Rights Watch, 2010. 'Zimbabwe: One Year On, Reform a Failure'. News Release. HRW, New York, 12 February.

Human Sciences Research Council (HSRC), 2008. 'Citizenship, Violence and Xenophobia in South Africa: Perceptions from South African Communities'. Democracy and Governance Programme, HSRC, Pretoria.

Huysmans, Jef, 2006. The Politics of Insecurity: Fear, Migration and Asylum in the EU. Routledge, Abingdon. 
Jordaan, Eduard, 2010. 'Fall from Grace: South Africa and the Changing International Order'. Politics 30(Supplement 1), December, 82-90.

Jordan, Pallo, 2008. 'Democracy is Not a Privilege'. ANC Today 8(19), 16 May.

Kersting, Norbert, 2009. 'New Nationalism and Xenophobia in Africa - A New Inclination?'. Africa Spectrum 44(1), 7-18.

Kriger, Norma, 2010. 'The Politics of Legal Status for Zimbabweans in South Africa'. In Zimbabwe's New Diaspora: Displacement and the Cultural Politics of Survival, eds. Joann McGregor and Ranka Primorac. Berghahn Books, United States.

Krause, Keith \& Williams, Michael C., eds., 1997. Critical Security Studies: Concepts and Cases. UCL Press, London.

Landau, Loren, 2004. 'The Laws of (In)hospitality: Black Africans in South Africa'. Forced Migration Working Paper no. 7. FMSP University of the Witwatersrand, Johannesburg.

Landau, Loren, 2005. 'Immigration and the State of Exception: Security and Sovereignty in East and Southern Africa'. Forced Migration Working Paper no. 15. FMSP University of the Witwatersrand, Johannesburg.

Landau, Loren, Kajaal Ramjathan-Keogh and Gayatri Singh, 2005. 'Xenophobia in South Africa and Problems Related to It'. Forced Migration Working Paper no. 13. FMSP University of the Witwatersrand, Johannesburg.

Landsberg, Chris, 2000. 'Promoting Democracy: The Mandela-Mbeki Doctrine'. Journal of Democracy 11(3), 107-121.

Lefko-Everett, Kate, 2008. 'Aliens, Migrants, Refugees and Interlopers: Perceptions of Foreigners in South Africa'. ePoliticsSA, edition 1, IDASA [electronic publication]. 
Available at : www.idasa.org/media/uploads/outputs/files/ePolitics\%2001.08\%20\%20Xenophobia.pdf [Accessed 6 November 2011].

Lipton, Merle, 2009. 'Understanding South Africa's Foreign Policy: The Perplexing Case of Zimbabwe'. South African Journal of International Affair 16(3), 331-346.

Loescher, Gil, 1992. Refugee Movements and International Security. Adelphi Paper no. 268. IISS, London.

MacDonald, David Alexander, 2000. On Borders: Perspectives on International Migration in Southern Africa. St Martin's Press, New York.

Mandela, Nelson, 1993. 'South Africa's Future Foreign Policy'. Foreign Affairs, 72(5), NovDec, 86-97.

Mawadza, Aquilina and Jonathan Crush, 2010. 'Metaphors of Migration: Zimbabwean Migrants in the South African Media'. In Zimbabwe's Exodus: Crisis, Migration, Survival, eds. Jonathan Crush and Daniel Tevera. SAMP and IDRC, Cape Town and Ottawa.

Mbeki, Thabo, 1998. 'The African Renaissance, South Africa and the World'. Speech by Deputy President Thabo Mbeki at the United Nations University, 9 April 1998. Available at www.dfa.gov.za/docs/speeches/1998/mbek0409.htm [Accessed 20 November 2011].

Mbeki, Thabo, 1999. 'Address of the President of South Africa, Thabo Mbeki at the Millennium Debate of the Joint Houses of Parliament', Cape Town, 19 November 1999. Available at www.dfa.gov.za/docs/speeches/1999/mbek1119.htm [Accessed 1 November 2011. 
Mbeki, Thabo, 2000. 'Statement of the National Executive Committee on the Occasion of the $88^{\text {th }}$ Anniversary of the ANC'. January $8^{\text {th }}$ Statement, delivered by Thabo Mbeki on behalf of the ANC's NEC. 8 January, Johannesburg.

McDonald, Matt, 2008. 'Securitization and the Construction of Security'. European Journal of International Relations 14(4), 563-87.

Misago, Jean Pierre, Loren Landau and Tamlyn Monson, 2009. Towards Tolerance, Law, and Dignity: Addressing Violence against Foreign Nationals in South Africa. IOM Regional Office for Southern Africa, Pretoria, February.

Moore, David, 2010. 'A Decade of Disquieting Diplomacy: South Africa, Zimbabwe and the Ideology of the National Democratic Revolution, 1999-2009'. History Compass 8(8), $752-767$.

Muzondidya, James, 2010. 'Makwerekwere: Migration, Citizenship and Identity among Zimbabweans in South Africa'. In Zimbabwe's New Diaspora: Displacement and the Cultural Politics of Survival, eds. Joann McGregor, Joann and Ranka Primorac. Berghahn Books, United States.

Ndlovu-Gatsheni, Sabelo, 2011. 'Reconstructing the Implications of Liberation Struggle History on SADC Mediation in Zimbabwe'. SAIIA Occasional Paper no. 92. South African Institute of International Affairs, Johannesburg.

Neocosmos, Michael, 2008. 'The Politics of Fear and the Fear of Politics: Reflections on Xenophobic Violence in South Africa'. Journal of Asian and African Studies 43(6), 586-594.

Nel, Philip, Ian Taylor and Janis van der Westhuizen, 2000. 'Multilateralism in South Africa's Foreign Policy: The Search for a Critical Rationale'. Global Governance 6(1), 43-60. 
Nyamnjoh, Francis B., 2010. 'Racism, Ethnicity and the Media in Africa: Reflections Inspired by Studies of Xenophobia in Cameroon and South Africa'. Africa Spectrum 45(1), 57 93.

Pahad, Aziz, 2000. 'Opening Address by Deputy Minister Aziz Pahad at the Conference on "Reflections on SA's Post Apartheid Foreign Policy"'. 26 September. Available at www.dfa.gov.za/docs/speeches/2000/paha0926.htm. [accessed 14 October 2011].

Polzer, Tara, 2009. 'Regularising Zimbabwean Migration to South Africa'. Migration Policy Brief. FMSP and CoRMSA, Johannesburg, May.

Polzer, Tara, 2010. 'Silence and Fragmentation: South African Responses to Zimbabwean Migration'. In Zimbabwe's Exodus: Crisis, Migration, Survival, eds., Jonathan Crush and Daniel Tevera. SAMP and IDRC, Cape Town and Ottawa.

SADC, 2011. Communiqué of the $31^{\text {st }}$ SADC Heads of State and Government Summit. SADC, 18 August, Luanda.

Sasse, Gwendolyn, 2005. 'Securitisation or Securing Rights? Exploring the Conceptual Foundations of Policies towards Migrants and Minorities in Europe'. Journal of Common Market Studies 43(4), 673-93.

Sharp, John, 2008. "Fortress SA": Xenophobic Violence in South Africa'. Anthropology Today 24(4), 1-3.

Steinberg, Jonny, 2011. 'Security and Disappointment: Policing, Freedom and Xenophobia in South Africa'. British Journal of Criminology, online advance access, first published online 24 August 2011. 
Stritzel, Holger, 2007. 'Towards a Theory of Securitization: Copenhagen and Beyond'. European Journal of International Relations 13(3), 357-383.

UNHCR, 2011. Global Trends 2010: Sixty Years and Still Counting. UNHCR, Geneva.

UNHCR, 2009. UNHCR Statistical Yearbook 2008: Trends in Displacement, Protection and Solutions. UNHCR, Geneva, December.

Vale, Peter and Sipho Maseko, 1998. 'South Africa and the African Renaissance'. International Affairs 74(2), 271-287.

Williams, Michael C., 2003. 'Words, Images, Enemies: Securitization and International Politics', International Studies Quarterly 47(4), 511-531.

Wæver, Ole, 1995. 'Securitization and Desecuritization'. In On Security, ed. Ronny D. Lipschutz. Columbia University Press, New York.

Wæver, Ole, Barry Buzan, Morten Kelstrup and Pierre Lemaitre, 1993. Identity, Migration and the New Security Agenda in Europe. Pinter, London.

\section{Endnotes}

\footnotetext{
${ }^{1}$ Lipton, 'Understanding South Africa's Foreign Policy'.

2 Jordaan 'Fall From Grace', 82. See also Alden and Soko, 'South Africa's Economic Relations with Africa', 388-389.

${ }^{3}$ Gerson, Michael, 'The Despots’ Democracy’, Washington Post, 28 May 2008.

${ }^{4}$ With a 354 percent rise in applications in 2008 - mostly from Zimbabweans - South Africa became the world's most popular destination for asylum seekers. UNHCR, UNHCR Statistical Yearbook 2008, 42-43. It has kept the top spot since. Of the 180,600 asylum applications lodged in South Africa in 2010, Zimbabweans accounted for 81 percent. That year South Africa received more annual applications than the United States, France, Germany and Sweden (the next four on the list of most popular asylum countries) put together. See UNHCR, Global Trends 2010, 24.

${ }^{5}$ Human Rights Watch, 'South Africa Country Summary', 115.

${ }^{6}$ On foreign policy, see e.g.: Alden and Le Pere, South Africa's Post-Apartheid Foreign Policy; Barber, 'The New South Africa's Foreign Policy', 1079-1096; Habib, 'South Africa's Foreign Policy’, 143-159; Hamill and Hoffman, 'Quiet Diplomacy or Appeasement?'; Jordaan, 'Fall from Grace', 82- 90; Lipton, 'Understanding South Africa's Foreign Policy, 331-346; Moore, 'A Decade of Disquieting Diplomacy, 752-767. On xenophobia and immigration, see e.g.: Landau, 'The Laws of (In)hospitality’; Human Sciences Research Council, 'Citizenship, Violence and Xenophobia in South Africa'; Dodson, 'Locating Xenophobia'; Danso and McDonald, 'Writing Xenophobia'; Crush, 'The Dark Side of Democracy '; Crush, The Perfect Storm; Misago et
} 
al, Towards Tolerance, Law, and Dignity; Neocosmos, 'The Politics of Fear and the Fear of Politics'; Sharp, "“Fortress SA"'; Polzer, 'Silence and Fragmentation'.

7 This will be set out in more detail in the next section.

${ }^{8}$ For some of the pioneers, see: Baldwin, 'The Concept of Security'; Wæver, 'Securitization and

Desecuritization'; Buzan et al, 'Security'; Krause and Williams, Critical Security Studies.

${ }^{9}$ see e.g. Loescher, Refugee Movements and International Security; Wæver et al, Identity, Migration and the New Security Agenda in Europe; Bigo, 'Security and Immigration'; Bigo, 'From Foreigners to "Abnormal Aliens"'; Guild, 'Editorial of Special Issue on 9/11 and Migration'; Guild and van Selm, International Migration and Security; Sasse, 'Securitisation or Securing Rights?'; Huysmans, The Politics of Insecurity; Givens et al, Immigration Policy and Security.

${ }^{10}$ For instance, at the outbreak of the 2011 uprising in Libya the foremost concern of the Italian government was not the fate of Libyan civilians. Instead Interior Minister Roberto Maroni feared a mass influx of North African migrants, constituting 'an invasion' that would bring Italy 'to its knees'. Quoted in Squires, Nick, 'Italy Fears Up To 1.5 Million North African Migrants', The Telegraph, 24 February 2011.

${ }^{11}$ Buzan et al, Security, 25-6.

${ }^{12}$ Buzan et al, Security, 26.

${ }^{13}$ Huysmans, The Politics of Insecurity, 2.

${ }^{14}$ Huysmans, The Politics of Insecurity, 26; Bigo, 'Security and Immigration'; Bigo, 'From Foreigners to "Abnormal Aliens"”.

${ }^{15}$ Stritzel, 'Towards a Theory of Securitization', 362-3. See also Balzacq, 'The Three Faces of Securitization', 173, 177; McDonald, 'Securitization and the Construction of Security'.

${ }^{16}$ Buzan et al, Security, 41-42.

${ }^{17}$ Stritzel, 'Towards a Theory of Securitization', 363.

${ }^{18}$ Barber, Mandela's World, 3.

${ }^{19}$ Mandela, 'South Africa's Future Foreign Policy'.

${ }^{20}$ Adebajo et al, South Africa in Africa, 27; Barber, Mandela's World, 152-157. Nel et al, 'Multilateralism in South Africa's Foreign Policy'.

${ }^{21}$ Nelson Mandela and Zimbabwe's president Robert Mugabe famously clashed over who should lead the Southern African Development Community's (SADC) Security Organ, leading to controversies over the two military interventions staged in the name of SADC in the 1990s. The South African led 'SADC intervention' in Lesotho in 1996 was disputed by Zimbabwe. Then the Zimbabwe and Angola led 'SADC intervention' in the DRC in support of that country's leader Laurent Kabila, was criticised and boycotted by South Africa. The SADC's Organ for Politics, Defence and Security was as a result moribund for nearly a decade. See Hammerstad, 'Domestic Threats, Regional Solutions?'.

${ }^{22}$ That South Africa requires a consensus seeking and cautious Africa policy due to its lack of legitimacy is argued strongly in Adebajo et al, South Africa in Africa.

${ }^{23}$ Mail \& Guardian, 'Mandela and Abacha to Solve Row Personally', 28 July 1997.

${ }^{24}$ Mandela, 'South Africa's Future Foreign Policy'.

${ }^{25}$ Mbeki was central to foreign policy development as Deputy President during Mandela's presidency, as well as during his own tenure as president from 1999 to 2008.

${ }^{26}$ Mbeki, 'The African Renaissance, South Africa and the World'; Pahad, 'Opening Address by Deputy Minister Aziz Pahad at the Conference on "Reflections on SA's Post Apartheid Foreign Policy"'. On South African multilateralism in the 1990s see Nel et al, 'Multilateralism in South Africa's Foreign Policy'.

${ }^{27}$ Vale and Maseko, 'South Africa and the African Renaissance'.

${ }^{28}$ Mandela, 'South Africa's Future Foreign Policy'.

${ }^{29}$ Mbeki, 'The African Renaissance, South Africa and the World'.

${ }^{30}$ Pahad, 'Opening Address by Deputy Minister Aziz Pahad at the Conference on "Reflections on SA's Post Apartheid Foreign Policy"'.

${ }^{31}$ Vale and Maseko, 'South Africa and the African Renaissance'.

${ }^{32}$ Mandela, 'South Africa's Future Foreign Policy', 87.

${ }^{33}$ Pahad, 'Opening Address by Deputy Minister Aziz Pahad at the Conference on "Reflections on SA's Post Apartheid Foreign Policy”'.

${ }^{34}$ Gumede, William, 'A Message to Gordon Brown: We Need African Solutions for Africa's Problems'. The Independent, 30 May 2007.

35 The African Union (AU) and the New Partnership for Africa's Development (NEPAD), both part of Mbeki's African renaissance initiatives, rely on funding from western donors. Nevertheless, the 2000s have seen many discussions on this 'partnership' deteriorating into accusations of western neo-colonialism, with South Africa providing a leading critical voice. The Zimbabwe situation has contributed to this fraught relationship, for instance when the 2007 Lisbon summit of the Africa-EU strategic partnership was overshadowed by the 
question of whether Zimbabwe's president Robert Mugabe should be invited. See e.g. Ian Traynor, 'Mugabe Invited to Lisbon Summit Despite Ban', The Guardian, 2 July 2007.

${ }^{36}$ Mandela, 'South Africa's Future Foreign Policy', 89.

${ }^{37}$ Mbeki, 'Address of the President of South Africa, Thabo Mbeki at the Millennium Debate of the Joint Houses of Parliament'.

${ }^{38}$ The ANC still defines itself as a national liberation movement and views its task, at least at the rhetorical level, to be that of spearheading national liberation and 'national democratic revolution'. See e.g. the ANC website, http://www.anc.org.za and the annual $8^{\text {th }}$ January Statements delivered by the National Executive Committee.

${ }^{39}$ ANC, 'Statement of the National Executive Committee on the Occasion of the $96^{\text {th }}$ Anniversary of the ANC'. This quote from 2008 is found under the exuberant heading 'There shall be peace and friendship!'.

${ }^{40}$ Mbeki, 'Statement of the National Executive Committee on the Occasion of the $88^{\text {th }}$ Anniversary of the ANC'.

${ }^{41}$ Landsberg (2000). 'Promoting Democracy', p. 109.

${ }^{42}$ Mandela (1993), 'South Africa's Future Foreign Policy'.

${ }^{43}$ E.g., for an account of the restrictions on the South African government's room to manoeuvre within SADC due to its Apartheid past, see Nathan, 'Consistencies and Inconsistencies in South African Foreign Policy', 367 368.

${ }^{44}$ Crush et al, Migration in Southern Africa, 1.

${ }^{45}$ Crush et al, Migration in Southern Africa, 8; MacDonald, On Borders, 12.

${ }^{46}$ Steinberg, 'Security and Disappointment', 9.

${ }^{47}$ Although the majority of asylum seekers are Zimbabwean. The level of abuse of the South African asylum system is illustrated by the applications for asylum lodged in 2009, and duly logged in government asylum statistics, by three persons from Iceland, two from Andorra, one from Denmark, one from New Zealand and one from 'Utopia'. See Government of South Africa, Report on 2009 Asylum Statistics, Table 3.

${ }^{48}$ Human Rights Watch, Prohibited Persons, 4.

${ }^{49}$ Nyamnoh, 'Racism, Ethnicity and the Media in Africa'.

${ }^{50}$ This discourse fits well with the understanding of securitisation set out by the Copenhagen School. See Buzan et al, Security.

${ }^{51}$ Bøås, “New” Nationalism and Autochthony - Tales of Origin as Political Cleavage'; Kersting, 'New

Nationalism and Xenophobia in Africa - A New Inclination?'.

${ }^{52}$ Muzondidya, 'Makwerekwere', 44.

${ }^{53}$ Crush, The Perfect Storm, 17; Danso and McDonald, 'Writing Xenophobia', 115-116.

${ }^{54}$ Immigrants were described in the media as a 'threat to South Africans as far as services are concerned'.

Quoted from a major South African newspaper, in Danso and McDonald, 'Writing Xenophobia', 125.

${ }^{55}$ Chirwa, 'Aliens and AIDS in Southern Africa', 59; Mawadza and Crush, 2010.

56 Thabo Mbeki, quoted in Chirwa, 'Aliens and AIDS in Southern Africa', 75.

${ }^{57}$ Quoted in Crush, The Perfect Storm, 17.

${ }^{58}$ Neocosmos, 'The Politics of Fear and the Fear of Politics', 590; Misago et al, Towards Tolerance, Law, and

Dignity, 17.

${ }^{59}$ Neocosmos, 'The Politics of Fear and the Fear of Politics', 590.

${ }^{60}$ Quoted in Misago et al, Towards Tolerance, Law, and Dignity, 16.

${ }^{61}$ Steinberg, 'Security and Disappointment', 12.

${ }^{62}$ Danso and McDonald, 'Writing Xenophobia', 116.

${ }^{63}$ Mawadza and Crush, 'Metaphors of Migration'; Nyamnjoh, 'Racism, Ethnicity and the Media in Africa'.

${ }^{64}$ Sharp, "Fortress South Africa", 2.

${ }^{65}$ Jonny Steinberg provides an excellent and well-documented analysis of how thwarted post-1994 expectations of socio-economic improvements together with Apartheid era style policing practices against undocumented migrants (brutal but with little impact on immigration levels), worked together to create conditions ripe for mob violence. They led to a sense among sections of the urban poor that African foreigners were not just a security threat, but one that the police could not deal with: 'When you throw foreigners out, they simply come back, the mobs were saying. We will make the city uninhabitable for them, and thus finish your work'. Steinberg, 'Security and Disappointment', 13.

${ }^{66}$ Lipton, 'Understanding South Africa's Foreign Policy', 339.

${ }^{67}$ FMSP, 'Zimbabwe and South Africa's International Reputation'.

68 Barber, 'The New South Africa's Foreign Policy'; Jordaan, 'Fall from Grace', 86.

${ }^{69}$ Habib, 'South Africa's Foreign Policy', 147.

${ }^{70}$ See e.g. Department of Foreign Affairs, South Africa in the United Nations Security Council (2007-2008).

${ }^{71}$ See Moore, 'A Decade of Disquieting Diplomacy'.

${ }^{72}$ Habib, 'South Africa's Foreign Policy'. 


\footnotetext{
${ }^{73}$ Moore, 'A Decade of Disquieting Diplomacy'.

${ }^{74}$ Moore, 'A Decade of Disquieting Diplomacy', 761-762.

75 Ndlovu-Gatsheni, 'Reconstructing the Implications of Liberation Struggle History on SADC Mediation in Zimbabwe', 7.

${ }^{76}$ ANC, $52^{\text {nd }}$ National Conference: Resolutions.

${ }^{77}$ Landau et al, 'Xenophobia in South Africa and Problems Related to It', 24.

${ }^{78}$ Misago et al, Towards Tolerance, Law, and Dignity, 8. See also Steinberg, 'Security and Disappointment'.

${ }^{79}$ Krieger, 'The Politics of Legal Status for Zimbabweans in South Africa', 86-87. Somalis, Nigerians and

Angolans were viewed even less favourably.

${ }^{80}$ Lefko-Everett, 'Aliens, Migrants, Refugees and Interlopers', 15-16.

81 Thabo Mbeki, May 2007, quoted in Polzer, 'Silence and Fragmentation'.

82 See eg. Crisp and Kiragu, Refugee Protection and International Migration.

${ }^{83}$ Information from interviews with refugee rights groups in South Africa, September 2010.

${ }^{84}$ E.g. in the period 2002-2004, the UK granted refugee status or humanitarian leave to remain to 27 percent of the more than 13,000 asylum seekers from Zimbabwe. See Doyle, "I Hate Being Idle", 10.

${ }^{85}$ Landau, 'Immigration and the State of Exception', 16-17.

${ }^{86}$ Polzer, 'Regularising Zimbabwean Migration to South Africa', 4.

${ }^{87}$ Polzer, 'Regularising Zimbabwean Migration to South Africa', 4.

${ }^{88}$ UNHCR, UNHCR Statistical Yearbook 2008; Government of South Africa, Report on 2009 Asylum Statistics.

${ }^{89}$ Desmond Tutu quoted in The Sowetan, 'Tutu Pleads for End to Violence', 20 May 2008.

${ }^{90}$ Mbeki and a South African Sunday Times editorial both quoted in Ian Evans, 'Mbeki Says South Africa

"Disgraced" by Xenophobic Riots as Death Toll Rises to 50'. The Independent, 26 May 2008.

${ }^{91}$ UNHCR, UNHCR Statistical Yearbook 2008; Government of South Africa, Report on 2009 Asylum Statistics.

${ }_{92}$ Quoted in Mail \& Guardian, 'Foreigners Not Taking SA Jobs, Says Minister', 27 June 2008.

${ }^{93}$ Crisp and Kiragu, Refugee Protection and International Migration.

${ }^{94}$ Jordan, 'Democracy is Not a Privilege'.

${ }^{95}$ Quoted in Los Angeles Times, 'Longtime South African Ally Rebukes Mugabe for Violence', 25 June 2008.

${ }^{96}$ Quoted in Los Angeles Times, 'Longtime South African Ally Rebukes Mugabe for Violence', 25 June 2008.

${ }^{97}$ Quoted in Banya, Nelson 'Death Toll Tops 1,100 from Zimbabwe Cholera' Reuters, 18 December 2008.

${ }^{98}$ HSRC, Citizenship, Violence and Xenophobia in South Africa, 8.

${ }^{99}$ Balzacq 'The Three Faces of Securitization', 182.

100 Jordaan, 'Fall From Grace'.

${ }^{101}$ See e.g. HRW, 'Zimbabwe: One Year On, Reform a Failure'.

102 Mbeki, quoted in BBC online news, 'Mozambicans Flee S Africa Riots', 26 May 2008.

${ }^{103}$ Williams, 'Words, Images, Enemies'; and Hansen, 'Theorizing the Image for Security Studies'.

${ }^{104}$ CNN online news, 'Hostels Raided in South Africa Clampdown', 22 May 2008.

${ }^{105}$ For an example of this (slightly) tougher line see SADC, Communiqué of the $31^{\text {st }}$ SADC Heads of State and Government Summit.
} 